\title{
Legitimacy and the courts: The forgotten story of Conway v Rimmer*
}

\author{
TT ARVIND AND LINDSAY STIRTON
}

\section{INTRODUCTION}

Despite generally being acknowledged as a landmark, ${ }^{1}$ Conway $v$ Rimmer ${ }^{2}$ is neglected today. ${ }^{3}$ In part, this is because it has become obsolete in a way that the other cases in the Quartet have not. Subsequent cases have built on Conway to move doctrine in a direction that is far more restrictive of the administration than Conway itself was. ${ }^{4}$ At the same time, the Scott Report, ${ }^{5}$ the advent of open government, and the new rights conferred by the Freedom of Information Act 2000, have so altered the functioning of government that the departmental practices which prompted Conway can appear to belong to a distant, almost quaint, era that has little relevance to the present day. Conway, from this perspective, may well have been a triumphant moment which played a key role in the historical process through which the modern doctrine of public interest immunity emerged, but it is a moment which belongs to the past of public law, not its present.

This chapter argues, in contrast, that Conway belongs not to a settled past but to an unsettled present. Judicial review today is back on the political agenda in a way it has not been for the past half-century. As this chapter shows, the story of Conway $v$ Rimmer sheds considerable light on why this is so. Our argument builds on a detailed examination, based on primary archival research, of the views of a group of persons whose perspective is not usually treated as central to the history of administrative law, namely, the individuals - civil servants, lawyers, and politicians - who made up the administrative branch when the leading cases of the 1960s were decided. ${ }^{6}$ As Section II discusses, Conway came at a time of intense and prolonged

We are grateful to the University of York for financial supporting our archival research in London, and to Richard Kirkham, Lord Reed, and other participants at the workshop on which this volume is based for helpful comments on previous versions of this chapter. For any errors that remain, each author blames the other. Unless otherwise specified, all references to archival material in this chapter refer to materials held at the National Archives, London.

1 It was expressly described as a 'landmark case' in In re A (A child) [2012] UKSC 60 [16] (Baroness Hale JSC). See also the discussion of Conway in T Endicott, 'Was Entick $v$ Carrington a landmark?' in A Tomkins and P Scott (eds), Entick v Carrington: 250 years of the rule of law (Oxford, Hart Publishing, 2017) 111-2.

2 Conway v Rimmer [1968] AC 910 (HL).

3 For example, it was the only case in the Quartet to be left out of the recent volume on leading cases in public law. See SS Juss and M Sunkin (eds), Landmark Cases in Public Law (Oxford, Hart Publishing, 2017).

$4 \quad R v$ Chief Constable of West Midlands, ex parte Wiley [1995] 1 AC 274.

$5 \quad \mathrm{R}$ Scott, Report of the Inquiry into the Export of Defence Equipment and Dual-Use Goods to Iraq and Related Prosecutions (1995-96, HC 115).

6 Some of the archival material we discuss has been previously considered by M Spencer and J Spencer, 
discussions within government about the disclosure of government records in litigation. These discussions began after Duncan $v$ Cammell Laird, ${ }^{7}$ and received added urgency with the enactment of the Crown Proceedings Act 1947 and the dramatic growth in the powers and functions of the post-War state. The discussions were complex and detailed, and included multiple interdepartmental committees as well as high-level Cabinet debates, culminating in a wide-ranging review of the law by the Law Reform Committee. Conway v Rimmer not only remade the law, but did so in a way which pre-empted the conclusion to which these internal processes were headed.

In Section III, we turn to a more detailed analysis of the positions and views seen in those discussions and debates. As we show, the doctrine of Crown privilege was strongly defended not just by civil servants, but also by government lawyers in the Treasury Solicitor's Office, including some, such as Lord Bridge, who would go on to become leading members of the judiciary. Underlying this support was a clear understanding, widely held amongst those working within the administrative branch, of their constitutional role and tasks, and a conceptualisation of the public interest that differed significantly from that held by the legal community. The nature of this 'administrative constitutionalism' has received little attention in the literature but, as we show, it is fundamental to understanding departmental behaviour in relation to Crown privilege.

There is much in the history we discuss that is of interest in purely factual terms. Our aim, however, is to consider the broader lessons which the history of Conway, and of judicial and departmental attempts to get to grips with the doctrine of Crown privilege, have to offer. In Section IV, we consider why the many internal efforts to reform Crown privilege failed, and use these as a basis for shedding light on why judicial review today remains so controversial. The answer, we suggest, lies in two interwoven themes: the institutional insulation between the judiciary and the administration, and the legitimacy of each institution as perceived by the other. A central function of law is to discharge what Atiyah termed the 'hortatory' function, of setting standards and communicating them to those subject to law in a way that enables them to follow it. ${ }^{8}$ This, we show, requires an active institutional dialogue between the courts and the regulated community. The reason for the failure of internal reform efforts, we argue, was that this dialogue and the mutual trust that underpins it was absent, resulting in the relationship between the courts and the administration descending into one of escalating mutual distrust. The resulting institutional tensions lie at the heart of what makes judicial review indispensable, but also controversial, fifty years after the Quartet. Conway is significant not only for its role as a stepping stone in the emergence of a specific modern doctrine, but because it highlights tasks, issues, and concerns that were left unaddressed in the making of modern judicial review, and that remain unaddressed today.

'Coping with Conway v Rimmer [1968] AC 910: How Civil Servants Control Access to Justice' (2010) 37

Journal of Law and Society 387. Their purpose in doing so was, however, different from ours, and as a result our conclusions differ quite significantly from theirs.

7 Duncan v Cammell Laird and Co Ltd [1942] AC 624 (HL).

8 PS Atiyah, 'From Principles to Pragmatism: Changes in the Function of the Judicial Process and the Law' (1980) 65 Iowa Law Review 1249. 


\section{THE LONG ROAD TO CONWAY V RIMMER}

\section{A. 'Class' privilege and its critics}

The starting point for understanding the law in relation to Crown privilege ${ }^{9}$ is the decision of Lord Simon in Duncan v Cammell Laird, ${ }^{10}$ which Conway overruled. Duncan v Cammell Laird arose out of a disaster involving an experimental submarine, the HMS Thetis. The widow of a deceased sailor brought a civil suit against the submarine's builders, and sought disclosure of several documents from Admiralty. Admiralty claimed Crown privilege. The case was appealed to the House of Lords, which allowed the claim. Lord Simon, who gave the leading speech, held that Crown privilege could be claimed either because production of the specific document would injure the public interest - for example, by harming national security or diplomatic relations - or because it fell within a class which had to be withheld from production to ensure the proper functioning of the public services.

The second of these grounds came to be known as the 'class' exception, and formed the core of the doctrine of Crown privilege until the changes brought in response to the Scott Report $^{11}$ and the decision in Ex parte Wiley, ${ }^{12}$ which led to the 'class' principle being virtually abandoned. The class exception covered situations where privilege was claimed not because the document in question contained information that should not be disclosed-indeed, in most cases where it was claimed, the content of the document was wholly unexceptionable. Privilege was claimed, rather, because the document belonged to a class or type of documents that the government for policy reasons would not disclose. Lord Simon explained the class principle with reference to candour. Candour and completeness are important for the functioning of public departments, and the Crown was entitled to use Crown privilege to refuse to disclose internal communications, if their disclosure would adversely affect the willingness of civil servants to produce candid and complete records.

Duncan v Cammell Laird was controversial almost as soon as it was decided. It was generally accepted to be correct on its facts: documents relating to the design of a submarine could not be released when the nation was at war. However, the breadth Lord Simon attached to Crown privilege was seen by many as going too far. Two points came in for particular criticism: class privilege, and the rule that it was ministers, rather than judges, who would decide whether disclosure of a document would be injurious to the public interest. These points were raised not just by the legal community, ${ }^{13}$ but also by business groups. ${ }^{14}$ Attempts to dismantle Crown Privilege or reduce its scope began almost immediately. The Crown Proceedings Act gave these attempts impetus and created a pressure point for reformers, because the Act meant that the Crown would now have to deal with requests for discovery in

9 Given the historical focus of this chapter, we refer to the doctrine as 'Crown privilege' rather than 'Public Interest Immunity', as that is the name by which it was known in the period which is the subject of this chapter.

10 Duncan (n 7).

11 Scott (n 5).

12 Wiley (n 4).

13 See eg LCO 2/5121, Report on Crown Privilege from the General Council of the Bar, February 1956.

14 See eg LCO 2/3363, Letter from the British Chambers of Commerce on the Crown Proceedings Bill, 30 May 1947. 
civil litigation. ${ }^{15}$

As a result of this pressure, the Lord Chancellor gave an undertaking to Parliament during the Third Reading of the Crown Proceedings Bill, to the effect that the importance of using Crown privilege sparingly would be communicated to all ministers. ${ }^{16}$ A memorandum was accordingly issued by the Prime Minister to all departments on how they should use the doctrine of Crown Privilege. ${ }^{17}$ The memorandum, which had been drafted by Sir Thomas Barnes, the Treasury Solicitor, ${ }^{18}$ closely followed the language of Duncan v Cammell Laird. ${ }^{19}$ Like that case, it identified two types of documents that were to be withheld from consideration: documents whose contents meant that they should not be produced, and documents which fell within a class that must be withheld from production. However, it also added further safeguards. It emphasised that documents should only be withheld from production 'after most careful consideration', and that the decision not to disclose must reflect the personal judgment of the minister, consulting with Law Officers if necessary. ${ }^{20}$

The controversy did not, however, die down. Whilst the judiciary accepted the existence of the doctrine of Crown immunity, there were numerous instances in which they made unfavourable remarks about the doctrine. As Sir Harold Kent put it in departmental correspondence, ' $[\mathrm{t}]$ he law is settled (by Cammell Laird), but the judges do not like it'. ${ }^{21}$ Public interest was also high. The Prime Minister received letters from members of the public 'complaining about the manner in which Crown privilege was being used to defeat the rights of the individual', and demanding a Royal Commission. ${ }^{22}$ Newspapers, too, regularly criticised the doctrine, as did judges who encountered it in practice. In Road Haulage Executive v Ministry of Supply, ${ }^{23}$ heard at Nottinghamshire Assizes, Finemore J strongly criticised a claim of Crown privilege by the Ministry of Supply in relation to a report of an accident at a depot, describing the doctrine as 'part of the stupidity we have got into these days that anything that is done in Government offices has to be kept secret', ${ }^{24}$ and his comments were representative of the general judicial sentiment. ${ }^{25}$

The result was a series of attempts within the administration to refine the practice.

15 Before the Act, requests for evidence could only be made through subpoena in actions against a third party - either a private person, or a crown servant behind whom the department was willing to stand. Because the Crown could not be sued in most civil actions, there was little scope for discovery in actions against the Crown. See TT Arvind, 'Restraining the State through tort?: The Crown Proceedings Act in retrospect' in TT Arvind and J Steele (eds), Tort Law and the Legislature: Common Law, Statute and the Dynamics of Legal Change (Oxford, Hart Publishing, 2012).

16 HL Deb 31 March 1947, vol 146, col 925.

17 The suggestion that the memorandum be issued by the Prime Minister was originally made by Professor AL Goodhart in correspondence with the Lord Chancellor's office. LCO 2/3363, Goodhart to Coldstream, 15 March 1947.

18 LCO 2/3363, Owen to Mayell, 14 August 1947.

19 The prevailing view within the government, in contrast with the view outside it, was that Duncan $v$ Cammell Laird 'had simply re-stated the law as it had been understood for a great many years'. LCO 2/5117, Note of Meeting held on Friday, 29th May 1953 to discuss the question of disclosure of documents by the Crown.

20 CAB 129/22/31, Crown Proceedings Act, Memorandum by the Prime Minister, 8 December 1947

21 TS 58/233, Kent to De Villiers, 8 March 1955.

22 TS 58/233, Minutes of the third meeting of the Committee on Crown Privilege, 28 April 1955

23 'Judge's Criticism of Secrecy' The Times (London, 26 June 1956).

24 Ibid.

25 For another example, see the remarks on class privilege in Ellis v Home Office [1953] 2 QB 135. 
In 1948, a meeting of the departmental solicitors and the Treasury Solicitor agreed on a common procedure to be followed before Crown privilege would be claimed. ${ }^{26}$ This was followed by a steady stream of departmental committees which, in response to public criticism and adverse judicial comments, debated ways to refine the doctrine and make it less controversial. The work of the first of these committees - the Kent Committee, set up in 1955 in response to a series of judgments critical of crown privilege-instantiates the tensions, pressures, and counterpressures involved in this process.

\section{B. Reforming the law from within: The Kent Committee and the failure of internal reform}

For much of the 1940s and 1950s, there were three broad strands of opinion in relation to Crown privilege. The first, strongly held by a substantial section of the legal community, was that Crown privilege was unjustifiable and should be abolished. The second, equally strongly held by a substantial section of the civil service, was that Crown privilege performed an essential function and should not be tampered with. Between the two extremes was a range of opinion within the civil service that recognised the source of the dissatisfaction with Crown privilege and sought to devise ways of ameliorating it, but ultimately failed to find a solution in which they could have confidence.

The Kent Committee was an example of this middle path. It was set up in 1955 to study departmental practice on Crown Privilege and examine whether it could be reformed. The committee was formally an 'official committee of inquiry' which, in the technical terminology used by the civil service at the time, signified a committee of officials (and not politicians or independent members) set up to inquire into an aspect of the current state of affairs within departments. The Chair of the committee was Sir Harold Kent, who had recently (in 1953) been appointed Treasury Solicitor after twenty years in the Parliamentary Counsel's office.

The committee was set up in the wake of growing judicial criticism of the extent to which departments claimed Crown privilege. The Treasury Solicitor's office had recently become aware that departmental practices on Crown privilege diverged substantially, and frequently failed to meet the requirements set out in the 1947 Memorandum and Duncan $v$ Cammell Laird. Although this was usually for practical reasons such as the demands on Ministerial time, it was feared that it would increase the criticism. ${ }^{27}$ There was a strong sense in the civil service that some action should be taken, although it was not clear what. In 1955, Sir Edward Bridges, the head of the Home Civil Service, wrote to George Coldstream, the Permanent Secretary to the Lord Chancellor's Office, suggesting the creation of an official interdepartmental committee to:

examine the circumstances in which, and the principles on which, the Crown claims privilege in legal proceedings for documents and oral communications, and to advise whether any modification of the present practice in this matter is possible and desirable. ${ }^{28}$

26 No record of the meeting appears to have been kept. The outcome is discussed in a later note by Harold Kent. See TS 58/233, Crown Privilege, 18 January 1955.

27 See TS 58/233, Crown Privilege, 18 January 1955.

28 LCO 2/5119, Bridges to Coldstream, 8 February 1955. 
Despite the breadth of the terms of reference, the principal aim was to have a fact-finding survey, which a more formal body could eventually take further. ${ }^{29}$ The official was to ascertain in what circumstances departments claimed privilege, with a view to examining which of these claims were excessive, and where the Government 'must stick in its toes' ${ }^{30}$ This, it was thought, would better inform Ministers deciding whether to claim privilege. ${ }^{31}$

Kent was a consummate insider, deeply loyal to the civil service and its ways of working. JAG Griffith would later remark that Kent, like many senior civil servants of his day, believed that there was 'very little wrong within the higher reaches of the civil service. ${ }^{32}$ This assessment is not entirely unfair. In a memorandum written some years later in response to public demands for more effective remedies against the state, Kent lamented the fallacy of those who made such demands 'in the assumption that, contrary to all experience, life is just. ${ }^{33}$ Kent was also sympathetic to bureaucratic secrecy, and would defend those who argued against publication of inspectors' reports before the Franks Committee. ${ }^{34}$

Despite this, the Committee began with a high degree of ambition. Its early circulars to departments show a willingness not just to systematise and harmonise, but also reconsider and narrow the basis of 'class' privilege. Options it floated included waiving privilege in all commercial cases, and drawing a distinction between internal documents recording matters of opinion (over which class privilege would be claimed) and those which recorded matters of fact (over which class privilege would ordinarily be waived, subject to requirements of confidentiality). ${ }^{35}$ Ultimately, however, the Committee decided against recommending radical change, focusing instead on harmonising practice and reducing the field in which 'class' privilege was claimed. In its final report, presented in April 1956, the Committee explained that it had decided not to pursue an approach of making practice more flexible by waiving Crown privilege 'whenever it seems reasonable to do so', because doing so threatened the entire basis of class privilege which depended on it being claimed consistently. This was, in part, because of the view that candour was foundational to existing practice. Even a file on a purely commercial contract, for example, typically contained 'frank discussions' and 'candid criticisms' about contractors, which were not always capable of factual substantiation, and involved delicate matters such as blacklisting individual contractors. ${ }^{36}$ The prospect of waiver would remove the 'feeling of security' on which this practice depended. ${ }^{37}$ Equally important, though, was a concern about the impact on the ability to defend claims before the judiciary:

if privilege is not claimed for a certain kind of document in one case because the requirements of justice seem particularly obvious in that case, and in a subsequent case privilege is claimed for the same kind of document because the requirements of justice seem less obvious, the inconsistency may be difficult to explain and

29 LCO 2/5119, Butler to Kilmuir, 14 February 1955

30 LCO 2/5119, Dobson to Coldstream, 9 February 1955.

31 LCO 2/5119, Coldstream to Kilmuir, 15 February 1955.

32 JAG Griffith, 'Draftsman', The Spectator (London, 29 September 1979) 23.

33 LCO 2/8439, Report by "Justice" on "The Citizen and the Administration", 3 November 1961.

34 Griffith (n 32).

35 TS 58/233, Departmental Circular on Crown Privilege, 31 March 1955.

36 CAB 134/1314, Report of Official Committee on Crown Privilege, para 42.

37 Ibid, para 8. 


\section{defend. ${ }^{38}$}

This concern influenced how the committee approached the way in which classes were defined, where its aim was to help departments avoid making 'difficult decisions in individual cases' because these might risk 'weakening the principle of "class" privilege'. ${ }^{39}$ Kent's own views are likely to have played a significant role in the committee's decision not to pursue broader changes. In correspondence with the Solicitor-General, Sir Harry Hylton-Foster, in September 1955, Kent emphasised the power which a more flexible approach to waiving Crown privilege would give the judiciary:

I feel very nervous about waiver, because if the House of Lords suggest that the Minister can waive class privilege in cases where the interests of justice seem to require it, the judges will almost always invariably press for it. ${ }^{40}$

The Committee's recommendations, accordingly, focused on harmonising and refining existing practice. Its work was not perfunctory. Some departments claimed privilege for a much broader range of documents than others. The Civil Services Commission, for example, claimed class privilege over all reports, medical or otherwise, and all inter-departmental minutes, ${ }^{41}$ whereas other departments, such as the Ministry of Labour and National Savings, were more open to disclosing medical reports in some circumstances. ${ }^{42}$ There was also wide variation in other everyday matters such as accidents. ${ }^{43}$ The Committee gave detailed consideration to the utility these claims had in litigation, and to whether privilege should continue to be claimed for that type of document. It ultimately made fourteen recommendations, which narrowed the ambit of some classes for which claims were regularly made and refined the process for making them.

Not everybody agreed with the abandonment of the more ambitious ideas floated in the initial circular. The Central Land Board, which had only recently suffered a significant defeat in Glasgow Corporation v Central Land Board, ${ }^{44}$ argued that rather than making minor modifications to practice, the Committee should be focusing on radically restricting the circumstances in which the class exception was claimed 'by contracting it to cover those classes which are already uniformly recognised by the courts, e.g. national defence, foreign relations, police reports, communications between the Lord Chancellor and Magistrates. ${ }^{45}$ Admiralty expressed similar misgivings, and pointed out that there was a distinct possibility that by only suggesting 'minor relaxations', the report would weaken 'departments' ability to hold the new line because of the illogicalities involved' while also leaving critics unsatisfied. ${ }^{46}$ Similar concerns were raised by officials in the Lord Chancellor's Office in their briefing note on the Report. The Report, they suggested, raised important questions of policy, because the Committee's determination to preserve the 'hard core' of the existing practice of Crown

38 Ibid, para 8.

39 CAB 134/1314, Report of Official Committee on Crown Privilege, para 8.

40 TS 58/233, Kent to Hylton-Foster, 30 September 1955.

41 CSC 5/995, Note to Hayes, 7 May 1956.

42 TS 58/234, Summary of Departmental comments, undated, p 4.

43 TS 58/233, De Villiers to Kent, 19 November 1955.

44 Glasgow Corporation v Central Land Board 1956 SC (HL) 1. The case held that Duncan (n 7) was not good law in Scotland, and courts there were not bound by a minister's certificate.

45 TS 58/234, Summary of Departmental comments, undated, p 2.

46 Ibid, p 4. 
privilege meant that the concessions it made were small. The issue for Cabinet to determine was whether there was even any point making 'minor concessions' which did little to address the judicial view that the administration was 'unnecessarily reticent in withholding documents'. ${ }^{47}$

Kent strongly rejected these critiques of his report. Critics assumed that change to the doctrine would come sooner rather than later, but there was no reason to suppose that change would come. Cammell Laird was 'not in eclipse for England', ${ }^{8}$ and 'without legislation, lawyers south of the Tweed will have to accept Duncan $v$ Cammell Laird' ${ }^{49}$ In the light of what would eventually happen in Conway, this attitude now seems complacent, but at the time it was widely shared. In October 1967, the Attorney General, Sir Elwyn Jones, confidently predicted that in his view, the Law Lords would 'confirm the existing law' when giving judgment in Conway $v$ Rimmer. ${ }^{50}$ The departmental records show that while the risk of judges embarrassing the government by making adverse comments in individual cases was recognised, it was not thought that there was any danger of radical changes to the law. The bigger concerns were public opinion, the attitudes of individual members of Parliament, and the pressures departments and ministers would come under to waive privilege in relation to specific documents in individual cases. It was towards equipping the civil service to resist the pressures of adhocism, and to put in place systems that would ensure consistency as well as fairness of practice, that internal efforts were primarily directed.

\section{From Kent to Conway: Incrementalism and its limits}

The Kent Committee's report was an internal document, which was not intended to be for public circulation or inform public debate. It had been set up with the expectation that a differently constituted body, such as a public committee or a Royal Commission, would consider the situation from a broader point of view. As it happened, however, other circumstances intervened to force ministers to take more rapid action.

In 1956, Jocelyn Simon, the Conservative member for Middlesbrough West, introduced an amendment to the Restrictive Trade Practices Bill. The amendment was on the subject of Crown privilege, and would have given judges the power to override a claim of crown privilege where the basis was that the disclosure was not in the public interest, while preserving the minister's final say on matters of national security. ${ }^{51}$ Jocelyn Simon was no stranger to the question of Crown privilege. In 1955, he had published a well-received paper in the Cambridge Law Journal which was very critical of the doctrine of Crown privilege, ${ }^{52}$ which the Kent Committee had read and considered. ${ }^{53} \mathrm{He}$ would also, as Baron Simon of Glaisdale, subsequently influence the development of the law on public interest immunity in leading cases

47 LCO 2/5123, Note on the Report of the Official Committee on Crown Privilege, 15 May 1956, p 2.

48 TS 58/234, Kent to Johnston, 14 May 1956.

49 TS 58/234, handwritten note, undated.

50 TS 58/741, Note of a Meeting held on Wednesday 18 October 1967 at the Home Office.

51 HC Deb 26 October 1956, vol 558, cols 946-957.

52 JES Simon, 'Evidence Excluded by Consideration of State Interest' (1955) 13 CLJ 62.

53 TS 58/233, Committee on Crown Privilege: Minutes of second meeting held on Friday 15th of April 1955 , p 4. 
such as Rogers $v$ Secretary of State for the Home Department. ${ }^{54}$

The government disagreed with Simon's proposed amendment. The view within Cabinet was that 'it would be wrong to allow the Court to question and, perhaps, reverse the executive decision of a Minister of the Crown in respect of the privilege of the Crown', and that making special rules in one Bill would set a bad precedent. ${ }^{55}$ Nevertheless, because Simon's views carried weight with MPs, the government felt that they merited a substantive response which would head off support for his amendment, and decided to do so by turning the recommendations of the Kent Committee into formal Government policy. On 3 May 1956, less than a week after the Kent Committee presented its report, Cabinet decided to appoint a Cabinet Committee to consider the report and make recommendations on its implementation, with a view to heading off Simon's amendment. ${ }^{56}$

The Cabinet Committee considered the Kent Committee's Report on 16 May 1956. The timetable was rushed, as Simon's amendment was listed for debate on 4 June. The Cabinet Committee largely accepted the Kent Committee's Report, agreeing in particular that ministers, and not courts, were the appropriate persons to decide where the balance lay between the public interest in good public administration and the public interest in the proper dispensation of justice. Judges were in no position to assess the first of these, ${ }^{57}$ and that the 'class' basis of privilege should be maintained to preserve candour and completeness, notwithstanding the expected pressure from the judiciary and MPs. ${ }^{58}$ The only departure from the Kent Committee's recommendation was to disclose even fewer documents than the Committee recommended. The Kent Committee had suggested that departmental minutes about road accident cases should be disclosed. The Cabinet Committee rejected this suggestion on the basis that it "would constitute a dangerous and significant inroad into the principle that departmental minutes should be protected. ${ }^{59}$ Cabinet approved the recommendations on 29 May. ${ }^{60}$ On 6 June, the Lord Chancellor made a statement to Parliament setting out what the new practice would be, substantially in the terms of the Kent Report with the additional qualifications imposed by the Cabinet Committee. ${ }^{61}$

One consequence was that the broader review that had been envisaged at the time the Kent Committee was set up never took place. Instead, the following eight years mostly saw a growing systematisation of the practices and procedures recommended by the Kent Committee and publicly announced in the 1956 statement by the Lord Chancellor. Following the 1948 Memorandum issued by Attlee, the Treasury Solicitor's department had developed litigation guidance and model forms to be used in responding to discovery. These were revised to take account of the 1956 Statement. In certain cases, departments were encouraged to continue to refuse to disclose documents, but by claiming other forms of privilege (such as legal

54 Rogers $v$ Secretary of State for the Home Department [1973] AC 388 (HL).

55 CAB 21/3004, Restrictive Trade Practices Bill Committee Stage: Note on Amendments_Clause 18, p 2.

56 CAB 128/30/32, Conclusions of a Meeting of the Cabinet held on 3 May 1956.

57 CAB 134/1314, Cabinet Committee on Crown Privilege: Minutes of a Meeting held on 16 May 1956, p 1.

58 Ibid, 2.

59 Ibid, 3; see also the report of the committee: CAB 129/81/127, Crown Privilege: Report of the Committee of Ministers, pp 109-110.

60 CAB 128/30/38, Conclusions of a Meeting of the Cabinet held on 29 May 1956, pp 4-5.

61 HL Deb 06 June 1956, vol 197, cols 741-747. 
privilege) rather than Crown privilege. ${ }^{62}$ Certificates claiming privilege were framed in generic terms, stating that the document belonged to a class whose disclosure was not in the public interest, but giving no hint of what that class might be. ${ }^{63}$ Ministers were encouraged to use an affidavit rather than a certificate if privilege was challenged. ${ }^{64}$

Common types of documents received considerable amounts of time and discussion. A lot of attention was devoted to the issue of medical disclosure ${ }^{65}$ and traffic accident reports, ${ }^{66}$, and special committees were formed to consider the issues of disclosing addresses held by the government (for example, to abandoned wives) ${ }^{67}$ and disclosing police reports and documents. ${ }^{68}$ There were occasional attempts to suggest reforms to existing practices, but most came to nothing. One of these, whose rejection seems particularly ironic given the outcome in Conway $v$ Rimmer, was a suggestion by the Attorney-General made in the context of discussions around the then-ongoing litigation in Auten $v$ Rayner, ${ }^{69}$ that Crown privilege should be waived where the document pertained to malicious prosecution.

For the most part, however, there were few radical changes in departmental practice. Departments recognised, and occasionally acknowledged, that what they were doing did not in fact comply with the rule in Duncan v Cammell Laird or Attlee's 1948 memorandum. In particular, Ministers were not personally taking decisions in the way Lord Simon, and Attlee, thought they should. ${ }^{70}$ Yet there was little impetus for change. The courts, despite their stated dislike for Crown privilege, did little to make departments' lives harder. In principle there was much the courts could have done. Precedent gave them some leeway to, for example, reject general claims of class privilege, and to require affidavits to have clear statements as to what the class was, and why that class deserved privilege. For the most part, however, they did not do this, confining themselves instead to making adverse remarks about the practice.

In 1964, this changed as a result of two developments, one legal and one political. The first was the decision in Merricks $v$ Nott-Bower ${ }^{71}$, in which the Court of Appeal, led by Lord Denning and Salmon LJ, ordered disclosure of documents despite a ministerial certificate that their disclosure was contrary to the public interest, holding that Lord Simon's ruling in Duncan v Cammell Laird was obiter as far as class documents were concerned, especially where the documents were unimportant. Although Lord Denning and Salmon LJ reiterated this in subsequent cases ${ }^{72}$ their approach was not taken up more broadly. Nevertheless, the possibility that disclosure might be ordered notwithstanding a ministerial certificate caused consternation

62 TS 27/1435, Litigation Division Circular No. 8, 1959: Discovery - claim for professional privilege, 30 October 1959.

63 See, for example TS 27/1435, Certificate by Secretary of State for Scotland, dated 25th June 1954.

64 TS 27/1435, Litigation Division Circular No 2, 1957, para 3(b).

65 TS 27/1436, Crown Privilege for medical documents, 26 January 1962.

66 TS 58/272, Claim for Crown and professional privilege in connection with traffic accidents reports.

67 LCO 2/5124-5129, Committee on Disclosure of Addresses.

68 LCO 2/7055-58, Official committee to consider the general policy regarding disclosure of police reports and documents.

69 Auten v Rayner [1958] 1 WLR 1300 and Auten v Rayner (No 2) [1960] 2 WLR 562. For a contemporary critical comment on the cases and the use of Crown privilege in them, see the case note by DE Nelson, 'Crown Privilege-Police Communications-Method of Claim to Privilege' (1960) 18 CLJ 129.

70 TS 58/740, Crown Privilege: Meeting at the Office of the Treasury Solicitor, 21 February 1964, p. 3

71 Merricks $v$ Nott-Bower [1965] 1 QB 57 (CA)

72 See especially In re Grosvenor Hotel, London (No 2) [1965] 1 Ch 1210 (CA) and Wednesbury Corporation $v$ Minister of Housing and Local Government [1965] 1 WLR 261 (CA). 
in government, where the prevailing view was that courts were not equipped to make this decision. As the Treasury Solicitor, WAH Druitt, put it:

The Courts can only be aware of one sector and not the whole field of the public interest. The Minister is responsible for this decision of policy and has to justify that policy to Parliament. For this reason it seems to me that it would be wrong for the Court to be given the power to override the Minister's decision if the Judge is of opinion that the public interest which the Minister has considered ought to give way to some other aspect of public interest. A conflict between a minister and the Court on this topic would be most regrettable. ${ }^{73}$

The second development was a speech delivered by the Prime Minister, Harold Wilson, to the Society of Labour Lawyers, one of whose themes was Crown privilege. ${ }^{74}$ Wilson took the issue up in government, seeking to require the explicit approval of the Lord Chancellor or the Prime Minister for claims of Crown privilege. ${ }^{75}$ Lord Gardiner, who was then the Lord Chancellor persuaded him that the issue was complex and would take time. ${ }^{76}$ This was not a delaying tactic: Gardiner was in favour of far-reaching changes, including giving judges rather than ministers the right to have the final say. ${ }^{77}$ After discussion, it was agreed that the Lord Chancellor would refer the matter to the Law Reform Committee. ${ }^{78}$ The specific issue referred to the Law Reform Committee was the issue of Crown privilege, and in particular whether class privilege claimed in the interest of 'freedom and candour' should continue. ${ }^{79}$

The Law Reform Committee had already been asked to take up the issue of evidence under a working group led by Lord Diplock. A separate sub-committee of the working group on evidence, led by Lord Pearson, was set up to consider Crown privilege. ${ }^{80}$ JAG Griffith was invited to join this sub-committee, and accepted. The Law Reform Committee's work remains largely unknown, because its report was never published. However, it proceeded to examine the issue very systematically, closely studying practice in other Commonwealth jurisdictions, including Australia, Canada, New Zealand, and South Africa, and also in Ireland. Submissions were also invited, and received, from a large number of individuals and groups, including the Society of Public Teachers of Law (as the Society of Legal Scholars was then called), several university departments of law, and a few leading scholars, including JDB Mitchell and HWR Wade. Comments were also received from other bodies, including the Institute of Professional Public Servants, and from a small number of members of the public. ${ }^{81}$ The Treasury Solicitor's Office made a submission on behalf of the entire administration, which was drafted on the basis of views received from other departments. ${ }^{82}$

The Law Reform Committee initially sought to avoid the need for legislation,

73 TS 58/740, Druitt to Dobson, 26 February 1964.

74 H Wilson, Liberty and the Law (London, Labour Party, 1964) 4.

75 PREM 13/1597, Prime Minister's Minute to the Lord Chancellor, 2 November 1964.

76 PREM 13/1597, Note by the Lord Chancellor, 2 November 1964.

77 TS 58/740, Note of meeting at Lord Chancellor's Department on 9 November 1964, para 4.

78 PREM 13/1597, Prime Minister's Minute to the Lord Chancellor, 2 November 1964.

79 PREM 13/1597, Cabinet Memorandum by the Prime Minister, 11 November 1964, para 3.

80 PREM 13/1597, Note by the Lord Chancellor, 9 November 1964.

81 LCO 65/292, Law Reform Committee Sub-committee 3, Crown Privilege: Documents circulated.

82 TS 58/741, Crown Privilege Correspondence. 
seeking, like the Kent Committee had, to recommend changes in departmental practice instead. Lord Pearson met a number of times with departments to find a solution that would enable practice to be changed voluntarily. These efforts did not succeed, however, and by the final draft of its report, the Committee had reluctantly concluded that it would need to recommend legislation. This was largely down to the 'class' basis of Crown privilege. The committee was faced, early on, with the problem - most cogently summarised by JAG Griffith - that if it accepted the government departments' 'candour and argument freedom' as an acceptable reason for privilege, then it would be unable to make more than 'the mildest of suggestions for reform' ${ }^{83}$ Lord Pearson, similarly, regarded claims 'made only on a class basis and having no other justification' as a 'very dubious category of claims for Crown privilege', which was probably an 'an illegitimate extension' of other, valid, categories of claims. ${ }^{84}$ The doctrine, he went on to say "is almost the opposite of "fiat justitia ruat caelum". It is justice, not the heaven, which falls down. ${ }^{85}$

This did not, however, mean that the Committee simply dismissed the views of the departments. On the contrary, they accepted that the departmental concern to protect 'candour and freedom' reflected a real underlying need which must be given weight (although a better term was desirable). The difficulty, however, was that the current system gave too little room to balance it against the countervailing interest, namely, the damage withholding documents did to litigants. The solution was to empower courts to ensure that the principle was not being wrongly applied. ${ }^{86}$ A report recommending legislation was drawn up, which would have resulted in a significant narrowing of class claims by eliminating 'general, vaguely defined' classes and requiring class claims to clearly specified, and also be weighed against the facts of a case ${ }^{87}$ The report also recommended subjecting claims to a greater degree of judicial scrutiny and control, and would have given the court the power to decline to give effect to a claim of Crown privilege if "it appeared that the interests of justice were paramount. ${ }^{98}$ In the meantime, however, Conway v Rimmer had begun making its way up the appellate hierarchy. The case was being keenly watched in the departments as well as by the legal community, and the publication of the report was put on hold while the House of Lords considered the appeal. ${ }^{89}$ Once the decision in Conway v Rimmer was issued, Lord Pearson decided that the report had been rendered redundant, and it was never published..$^{90}$

83 LCO 65/295, Note from JAG Griffith

84 LCO 65/295, Memorandum from the Chairman

85 LCO 65/295, Note from Lord Pearson, undated.

86 LCO 65/294, Minutes of Fifth Meeting held on Tuesday, 19th April 1966, para 7-14. HWR Wade took a similar stance in his memorandum to the Committee, suggesting that the problem arise from the fact that the executive was in the position of "being final judge in its own cause and of having to decide without hearing both sides of the case". LCO 65/292, Documents circulated CP 6: Memorandum by Professor Wade.

87 LCO 65/297, Law Reform Committee, Second Revised Draft Report of the Sub-committee on Crown Privilege, para 19 .

88 Ibid, para 18, 20. Cabinet minutes, as well as documents relating to national security or containing diplomatic secrets were to be exempt from judicial scrutiny. Ibid, para 5, 18 .

89 LCO 65/297, Letter from the Chairman to the Assistant Secretary, 13 June 1967; LCO 65/296, Crown Privilege: Record of vote on Lord Pearson's suggestion, June 1967.

90 TS 58/923, Dobson to Armstrong, 2 July 1969. 


\section{Conway and its aftermath}

Conway v Rimmer related to a class of documents that had long been the subject of a claim of Crown privilege, namely, probationary reports. Michael Conway, a constable, had been dismissed from the Cheshire constabulary following an accusation of theft against him. He had been prosecuted for the alleged theft on the recommendation of his superintendent, Thomas Rimmer, but had been acquitted. Despite his acquittal, he was dismissed on the basis of a probationary report. He thereupon sued Rimmer for malicious prosecution, and sought discovery of the confidential probationary reports made about him, as well as of Rimmer's report recommending his prosecution. Class privilege was claimed, and the Home Secretary filed an affidavit the effect that the documents sought fell within classes of documents that could not be disclosed. The District Registrar ordered the documents to be produced notwithstanding the certificate. On appeal, Browne J in the High Court set aside the Registrar's order. Even if the court had a residual power to override a certificate (an issue which Browne J did not finally decide) it would only be appropriate to do so if the claim of privilege was 'ridiculous or wholly unreasonable or wholly unnecessary. ${ }^{91}$ That bar had not been crossed in this case. Conway appealed. The Court of Appeal dismissed the appeal holding, over a strong dissent from Lord Denning, that the decision of Lord Simon in Duncan v Cammell Laird ${ }^{92}$ was binding, and under it the certificate of a minister was conclusive leaving judges with no power to themselves inspect a document to decide whether it ought to be privileged. ${ }^{93}$

Conway appealed to the House of Lords, which allowed the appeal and ordered production of the documents. Invoking the recently issued Practice Statement, ${ }^{94}$ the House of Lords overruled Duncan $v$ Cammell Laird and held by a 4:1 majority that it no longer represented the law of England. ${ }^{95}$ Lord Reid in his leading speech did not question ministerial certificates granted on the basis of the content of a document. 'However wide the power of the court may be', he held, 'cases would be very rare in which it could be proper to question the view of the responsible Minister that it would be contrary to the public interest to make public the contents of a particular document. 96 This did not, however, hold for class privilege, where the effect of the doctrine's application in individual cases was frequently 'little short of being ridiculous. ${ }^{97}$ As Lord Reid saw it, the problem lay in the fact that 'in a doubtful case the alleged public interest in concealment should be balanced against the public interest that the administration of justice should not be frustrated.' A minister however, 'has no duty to balance these conflicting public interests'. ${ }^{98}$ Treating a minister's decision as conclusive meant 'not only that very serious injustice may be done to the parties, but also that the due administration of justice may be gravely impaired for quite inadequate reasons,' as 25 years of experience

91 Conway v Rimmer (QB, 23 February 1967) 9. The High Court judgment is not reported, but a copy is available in the Law Reform Committee's papers in LCO 65/296.

92 Duncan (n 7).

93 Conway v Rimmer, [1967] 1 WLR 1031 (CA).

94 Practice Statement (Judicial Precedent) [1966] 1 WLR 1234.

95 Lord Upjohn, whilst concurring in the result, would have preferred to distinguish Duncan v Cammell Laird without overruling it. Conway (n 2) 990.

96 Conway (n 2) 943.

97 Ibid 950.

98 Ibid. 
since Duncan v Cammell Laird had shown. ${ }^{99}$ It was, therefore, the courts who should balance the two conflicting public interests at issue. ${ }^{100}$

Lord Reid also rejected the argument in relation to candour. Using Cabinet minutes as his example, he suggested that the true issue was not candour but rather the danger that the 'premature disclosure' of documents connected with policy-making, whether in Cabinet or in departments, would 'create or fan ill-informed or captious public or political criticism' by exposing the inner workings of government 'to the gaze of those ready to criticise without adequate knowledge of the background and perhaps with some axe to grind.' This did not, however, apply to routine documents of the sort that were more typically the subject of class claims. ${ }^{101}$ Whilst there were good reasons to adopt a cautious approach in relation to police documents, this did not apply to probationary reports. Nor, given Conway's acquittal, did it apply to Rimmer's report recommending his prosecution. The Court was not therefore bound by the minister's certificate, but could form its own opinion. ${ }^{102}$ Lord Reid then proceeded to examine the documents, and held that there was nothing in them to suggest that their disclosure would be 'prejudicial to the proper administration of the Cheshire Constabulary or to the general public interest', and ordered their disclosure. ${ }^{103}$

The victory in the House of Lords did not ultimately help Conway, who lost when the case went back to trial. ${ }^{104}$ The impact of the House of Lord's ruling on the government was, however, considerable. Conway $v$ Rimmer had been deliberately taken further by the government, because it was seen as 'an exceedingly good case to fight' as the documents 'could not possibly be disclosed' in proceedings. ${ }^{105}$ The decision was, therefore, wholly unexpected. There was concern about the high degree of uncertainty which departments would face in their work. ${ }^{106}$ The Treasury Solicitor's department took on the task of drafting new guidance for departments. The work was led by Charlton, who had also drafted the joint submission to the Law Reform Committee. The main thrust of the work was preserving as much as possible of the existing practice on claiming privilege on the basis of 'class'. There was considerable regret that the requirements of candour and completeness were not given weight by the House of Lords, but the overall tone of discussions was constructive. It was recognised that the decision had made it necessary to change existing practice, but there was also a clear desire to ensure that the changes went no further than absolutely necessary. ${ }^{107}$

For much of 1968 and the first half of 1969, discussions revolved around the class-

99 Ibid 951.

100 Ibid.

101 Ibid 952.

102 Ibid 954.

103 Conway v Rimmer [1968] 2 WLR 1535 (HL).

104 The claim was dismissed on the basis that Rimmer had not acted with malice or without probable cause in the legal sense, in part because the DPP had been consulted. Thomas Rimmer was not well liked, and his leading counsel took the view that were he to give evidence, the jury would form an unsympathetic view of him and sympathise with Conway. He therefore sought, successfully, to have the claim dismissed when the plaintiff had concluded his case, recording that it took 'some courage' for the judge to do so. See R Waterhouse, Child of Another Century: Recollections of a High Court judge (London, Radcliffe Press, 2013) 143-4.

105 TS 58/741, Minute of a conference at Mr. Nigel Bridge's chambers on 19 October 1966

106 CAB 165/925, Guidance to departments on Crown privilege, January 1971.

107 See eg TS 58/921, Jones to Charlton, 24 April 1968. 
content distinction, the utility of 'content' as a basis for refusing disclosure, and the ways if any in which class could continue to play an operative role. Although candour had been given short shrift by the House of Lords in Conway, the view was strongly expressed that it was candour that remained the key issue in disclosure, rather than the fear of criticism, and that it was a nettle that needed to be grasped. ${ }^{108}$ Officials in the Lord Chancellor's Office argued that the old approach was not compatible with Conway. The default approach after Conway had to be to disclose documents unless harm (and not merely embarrassment) would result from disclosure. Whilst this would affect candour, they questioned whether candour was really such a big issue. ${ }^{109}$ Lord Pearson, whose views on the draft memorandum of guidance were sought by the Treasury Solicitor's department, similarly recommended a more generous approach to be taken to waiving class privilege. ${ }^{110}$ But this view was not widely shared outside the Lord Chancellor's Office. The preference was, instead, for adopting an even more inflexible approach to disclosing documents within an excepted class. ${ }^{111}$ The reaction ensured that both class and candour would remain a fundamental part of the departments' approach to Crown privilege until they were swept away in the aftermath of the changes that followed the Scott Report ${ }^{12}$ and Ex parte Wiley $^{113}$.

\section{AN ALTERNATIVE VIEW: PRINCIPLE, PRAGMATISM, AND THE NEED FOR CROWN PRIVILEGE}

The story thus far might seem a familiar tale of obstructive civil servants defending their privileges against the demands of justice. In reality, the picture is more nuanced. Civil servants understood that Crown privilege was a controversial and unpopular doctrine, and they also understood that it had the potential to cause real injustice. Nevertheless, they felt that the doctrine was necessary, and that the potential for injustice was best ameliorated not by diluting the doctrine, but by creating procedures and processes by which pragmatic justice could be done.

In correspondence with the Law Reform Committee, officials insisted that they knew of few or no cases in which Crown privilege caused injustice. This does not appear to be a disingenuous claim. Officials genuinely believed that most issues could be avoided through appropriate practices, and the archival record shows that the administration could go to considerable lengths to ensure a just outcome where a decision was made to withhold documents from production. The actions taken by administrators in connection with the litigation brought by Barbers Removal Services Ltd against the Minister of Housing and Local Government is a typical example.

The case arose out of a compulsory acquisition order that had been made over property in Stockport, for the purpose of building a new fire station. The affected persons challenged the order and sought disclosure of the report of the Fire Inspector who had made the

108 TS 58/922, Hall to Charlton, 26 November 1968.

109 TS 58/922, Note from the Lord Chancellor's Office, 4 February 1969.

110 TS 58/923, Pearson to Dobson, 2 November 1969, pp. 7-9.

111 TS 58/922, Note from Hankey, 17 February 1969.

112 Scott (n 5).

113 Wiley (n 4). 
final decision on the site. The Fire Inspector's report revealed a serious irregularity in the decision-namely, that the Inspector had a private conversation with the local fire chief after the public inquiry had been conducted. The points emerging from this conversation influenced the final decision, but were not disclosed to the persons whose property was acquired, nor were they given a chance to respond to them. Inspectors' reports were part of a class over which privilege was customarily claimed in the interests of candour. The plaintiff was unaware of the irregularity. The decision in this case was to concede the challenge without disclosing the document, thus ensuring that the substantive dispute received a just resolution, while also protecting candour. ${ }^{114}$

This is not to say that the conduct of the administration was perfect or above reproach. Crown privilege did produce injustices, as we have discussed above. Nevertheless, the manner in which the administration dealt with this case was by no means exceptional, and it demonstrates that departmental pragmatism could mitigate the harm caused by Crown privilege, at least when it operated at its best. In contrast, officials did not see any way of mitigating the harm to public administration which they believed would flow if the 'class' basis for claiming Crown privilege were to be abolished or diluted. Underlying this lay a clear administrative constitutionalism - a phenomenon by which administrative actors not only apply constitutional requirements, but seek to play a part in the process by which constitutional doctrines and ideas are adapted to a changing environment. ${ }^{115}$ Three themes, in particular, emerge from the archival record as underlying the civil servants' constitutional worldview and their resistance to radical reform: the importance they attached to candour, the difficulty they had in articulating an alternative, and their feeling that the judiciary neither understood nor cared to understand the needs of administration.

\section{A. Candour and the 'class' basis of Crown privilege}

The departmental record shows an attachment to candour and completeness that was real, and not merely a convenient fig leaf to conceal a different motive. Civil servants very strongly held the view that candour would become impossible unless the 'class' rule was very strictly observed. ${ }^{116}$ Civil servants would not be candid or make complete records if they thought there was any chance that the document might be disclosed, or if there was any possibility that the discovery process might mean that 'the Courts and Counsel could have "a field day amongst the files". 117 They would, in particular, be reluctant to record any views that might "embarrass the whole administration of government.' The necessary implication was that maintaining candour and completeness required that:

the confidentiality of the document must be established for all time at the moment it comes into existence - it follows inevitably that the writer of a document of that class must know when he puts pen to paper that the document is never going to be

114 LO 2/760, Note for the Attorney General, 30 November 1961.

115 See GE Metzger, 'Administrative Constitutionalism' (2013) 91 Texas Law Review 1897.

116 TS 58/233, Departmental Circular on Crown Privilege, 31 March 1955.

117 TS 58/233, Minutes of the First Meeting of the Committee on Crown Privilege, 24 March 1955. 
disclosed..$^{118}$

This was only possible through a rigid and robustly defended conception of 'class' privilege. A procedure based purely on content would not serve this purpose, because the official at the time of producing the document would not be sure whether or not the advice was being given in confidence. $^{119}$

This view was held not only by administrators, but also by senior politicians. It underpinned both Attlee's 1947 memorandum, ${ }^{120}$ and the Cabinet Committee's adoption of the Kent Committee Report in 1956. ${ }^{121}$ Administrators also found confirmation of this view in the private sector. As part of the work of the Kent Committee, Kent had met with ICI and Unilever to gauge how they dealt with discovery in civil proceedings, and the impact it had on their functioning. These meetings suggested that the possibility of disclosure had indeed harmed candour in the private sector. Engineers no longer wrote reports expressing views as to the likely causes of accidents, for fear of the embarrassment caused if such reports had to be disclosed. Companies were very careful about what was written down, with confidential information only put on paper where absolutely necessary. ${ }^{122}$ The problem was likely to be even more acute for departments, whose their actions were subject to challenge on the basis of vires and subject to a higher standard of conduct than private companies, but who also had a greater need for careful recording of matters than business. ${ }^{123}$

In making this point, administrators were not engaging in a single-minded or unreflective defence of secret government. The practice, for example, was to waive even class privilege for documents required by individuals facing serious criminal charges. ${ }^{124}$ The Kent Committee report (which, it should be remembered, was not written for publication, and is therefore likely to represent the true views of its authors) welcomed the fact that ministers were now more inclined 'to give full for their decisions, thus giving better opportunities for effective challenge in the courts as well as in Parliament.' This, they said, created a better balance between 'the needs of good administration and the rights of persons affected by Government decisions.' ${ }^{125}$ But this did not apply to civil servants. Government decisions and actions should be examined in the light of the positions taken by ministers, rather than in the light of opinions expressed by civil servants.

Scholars of public administration have described the relationship between civil servants and their ministers as founded on a 'public service bargain'. ${ }^{126}$ Under this bargain, in return for agreeing to 'anonymity, some sacrifice of political rights and proficient performance', British civil servants were assured 'prominent careers, honours and a six hour working day when the middle classes wanted just that, and neutrality was possible, credible and

118 LCO 2/5122, Rankin to Bancroft, 5 June 1956.

119 CAB 134/1314, Report of Official Committee on Crown Privilege, para 49.

$120 \mathrm{CAB} / 129 / 22$, Crown Proceedings Act 1947: Memorandum by the Prime Minister

121 CAB 134/1314, Cabinet Committee on Crown Privilege: Minutes of a Meeting held on 16 May 1956, pp 12.

122 TS 58/233, Minute of meeting with the Secretary of Unilever Ltd, 28 October 1955.

123 CAB 134/1314, Report of Official Committee on Crown Privilege, para 50.

124 TS 27/1530, Newman to O’Brien, 6 August 1953.

125 CAB 134/1314, Report of Official Committee on Crown Privilege, para 47.

126 C Hood and M Lodge, The Politics of Public Service Bargains: Reward, Competency, Loyalty - and Blame (Oxford, OUP, 2006). 
inexpensive'. ${ }^{127}$ Anonymity was a key component of this bargain. At one level, anonymity represented a deferral of credit. A civil servant would no longer receive immediate credit for their contribution to policy-making or administration. Rather, the reward, if it came, would take the form of honours for their contribution over the course of their career. Equally significantly, however, anonymity also represented a shield. The ability to express views freely and frankly without fear of publicity, and to have these views weighed in any decision or giving of advice was one of the privileges of a civil service career, and part of what they had to offer in terms of proficient advice. This was not simply a matter of bureaucrats defending their interests. Rather, this 'highly complicated bargain' was the foundation of the working relationship between ministers and civil servants. Aware of the temptation on the part of Ministers to 'shuffle out' of their part of the bargain, it is perhaps not surprising that officials were highly sceptical of any attempts to interfere with the existing 'bright line' on class privilege. In the context of 1956, when memory of the Crichel Down affair was still fresh (and in which, as we now know, civil servants were unfairly blamed), their concerns about the consequences of the dilution of anonymity cannot be said to be unreasonable. ${ }^{128}$

\section{B. A lack of alternatives}

A second theme that emerges from the archival record is the civil service's lack of institutional capacity to frame alternative ways of protecting candour and completeness. The civil service was not attached to Crown privilege. As we have discussed above, they acknowledged its limitations, and the record displays a strong willingness to consider alternative policies. The difficulty they faced, however, was actually formulating an alternative that they could be confident would work without having unintended side effects.

Throughout the period between the entry into force of the Crown Proceedings Act 1947 and the decision in Conway v Rimmer, discussions were taking place within departments about the problems created by class claims. Many suggestions were innovative and interesting. In 1965, for example, Kean, who worked within the section of the Treasury Solicitor's department that assisted the Ministry of Power, came up with a possible alternative to class privilege. With the Law Reform Committee's review in progress, he suggested that departments abandon class claims and, instead, create a new privilege expressly designed to provide candour. Instead of a certificate that a document fell within a class that was not disclosed in the public interest, he suggested that the Minister issue a certificate that the document originated in a discussion, the candour of which would have been impaired had it been known that it would be disclosed. ${ }^{129}$ This proposal, which came to be known as the 'Kean Formula', attracted considerable interest and discussion and it was generally thought to be more defensible than class claims. Ultimately, however, the civil service was not able to articulate it in a way that they could be confident would be applied as intended by the judiciary. ${ }^{130}$ Other attempts to articulate alternate bases for refusals to disclose documents-ranging from analogies with

127 B Schaeffer, The Administrative Factor (London, Cass, 1973) 252.

128 I Nicholson, The Mystery of Crichel Down (Oxford, OUP, 1986).

129 TS 49/284, Keane to Charlton, 19 March 1965, para 7.

130 TS 49/284, Minute by Norris on Crown Privilege, 23 August 1965. 
trustees or juries ${ }^{131}$ to summarising the factual component of documents without actually disclosing any documents, ${ }^{132}$ or simply covering up expressions of opinion in documents while letting statements of fact be disclosed ${ }^{133}$ _faced similar problems.

This points to a deeper issue, namely, the lack of institutional capacity to resolve a problem which the civil service recognised was all too real, and to which they were attempting to find workable solutions which would not create further problems. There was a genuine desire to administer well, and in the public interest; but in sharp contrast to the way in which things were seen by lawyers and judges, the issue of disclosure was seen as being relatively peripheral to this goal. As the departments saw it the question was simply one of whether existing practice should be liberalised even further, and not (as the legal profession saw it) a fundamental question of the rule of law. Against this background, it is perhaps somewhat more understandable that civil servants defaulted to supporting the status quo-a natural human response to a difficult dilemma.

\section{Judges and the public interest}

A third theme in departmental discomfort with diluting Crown immunity was the view that judges were not well placed to make a decision in relation to balancing the interests of good administration (which weighed against disclosure) against the interests of the proper administration of justice (which weighed for disclosure). Ministers, in contrast, were in a much better position to do so:

A judge can never be in as good a position as a Minister of the Crown, responsible to Parliament, to make a true assessment of the needs of the proper functioning of the public service. To say this is certainly not to cast a slur on the Judiciary. For the Judges themselves recognise, and have always recognised, that there are some issues which they are not competent to decide, e.g. in the realm of foreign affairs, and which in the nature of things are rightly left to the Executive. ${ }^{134}$

As this quote suggests, two justifications were advanced in support of this view. The first was the principle of Parliamentary responsibility. A minister who happened to get the balance wrong was accountable to Parliament. A judge who misjudged the balance was accountable to noone. ${ }^{135}$ The second was that ministers alone had the ability to judge what the interests of good public administration required. Judges did not. Ministers could explain the relevant interest in their affidavit, but it would ultimately lie outside the judge's experience. Ministers, in contrast, had the ability to consult the Law Officers for advice on where the interests of the administration of justice lay, and draw on that advice in striking a balance between the two competing interests.

As with the issue of candour, administrators's views on this were supported by ministers, including at the highest level. Attlee's 1947 Memorandum, for example, pointed out that deciding where the public interest lies frequently involved matters that were not

131 TS 58/740, Johnstone to Charlton, 23 March 1965, pp 4-5.

132 TS 58/741, Druitt to Bourne, 13 December 1965.

133 LCO 2/5117, Discovery of Documents by the Crown: Note of a meeting held on Tursday, 2nd July 1953.

134 LCO 2/5122, Rankin to Bancroft, 5 June 1956.

135 TS 58/740, Druitt to Dobson, 26 February 1964. 
considerations of law. This made it necessary to leave it to ministers, rather than judges, to deal with the matter, as they alone had the necessary information at their disposal. ${ }^{136}$ Officials also felt that judges and lawyers were a little too ready to condemn the administration without seeking to properly understand its functioning. This view was not entirely without basis. The statements of Finemore J in Road Haulage Executive v Ministry of Supply, discussed in Section 1 above, provide an excellent example. The document at issue in that case was a report of an accident. Departmental records, however, reveal that the reason the document was not produced was that it did not exist. An inquiry into the accident was conducted, but no written report was produced; and the documents for which Crown privilege was claimed were not a report, but departmental minutes and internal correspondence. ${ }^{137}$ Incidents of this type were seen by the departments as being a frequent reminder of the distance between the worlds of the judiciary and the administration.

\section{BROADER THEMES: COURTS, ADMINISTRATORS, AND THE LIMITS OF LEGITIMACY}

This paper has sought to shed light on why Conway $v$ Rimmer ever came to be decided. At one level, the fact that it did is surprising in the light of the historical record. The civil service did not ignore the importance of balancing the interests of effective public administration against the interests of the administration of justice. On the contrary, they embraced it. Equally, they were not blind to the potential for injustice implicit in the doctrine of Crown privilege. On the contrary, they sought to take steps to ameliorate it. On the other side, lawyers too were not blind to the civil service's needs. Leading legal figures such as Lord Pearson expressly sought to engage with the civil service and reach a mutually acceptable compromise that could be voluntarily implemented. Why, then, did these efforts fail? In this section, we tentatively advance a diagnosis centred around two related factors, one to do with institutional insulation between the judiciary and the administration, and the other to do with the legitimacy of each institution as perceived by the other. These factors, we suggest, are not merely of historical interest: there is reason to think that they continue to affect judicial review today.

Let us begin with the first of these - the issue of institutional insulation. The failure we have just discussed is at its heart an institutional failure. There was no institution which could work out a solution that took on board both the views of civil servants on the needs of good administration, and the views of the legal profession and judiciary on the requirements of the rule of law, whilst also having an eye on the actual types of, and extent of, hardship caused by departmental practice on Crown privilege. The existence of this institutional gap is not new. Scholars in the 1960s, most notably JDB Mitchell, argued strongly that it required the creation of a new type of institution, along the lines of the French Conseil d'État, which would have the ability to consider questions such as these in a trans-departmental context, examining whether a practice is justified and how it might be modified in a way that does not unduly harm the interests of good administration. ${ }^{138}$ The nature and extent of its consequences, however, have

$136 \mathrm{CAB} / 129 / 22$, Crown Proceedings Act 1947: Memorandum by the Prime Minister, para 5.

137 LCO 2/5122, Kent to Manningham-Buller, 26 June 1956.

138 See TT Arvind and L Stirton, 'The curious origins of judicial review' (2017) 133 LQR 91. 
only started to become clear with more recent empirical work into the impact of judicial review on public bodies. Two points emerge from this empirical work. The first is that judicial review does lead public bodies to alter the way in which they work, and that these changes can have beneficial effects on the quality of public administration. ${ }^{139}$ The second is that public bodies often struggle to make sense of the outcomes of judicial review, which can very often leave them bewildered in relation to what they are expected to do. ${ }^{140}$

In this chapter, we have suggested that the problem is in part one of the failure of the judiciary to guide the development of - or even note or engage with - the administrative constitutionalism that underpins the administration's own view of its role, mission, and priorities. Viewing the problem in terms of institutional theory, and in particular through the lens of institutional insulation, can help us make better sense of why this failure is problematic. Patrick Atiyah demonstrated that law not only performs a dispute settlement function, but also what he termed a 'hortatory' function, of setting standards which people subject to it are expected to follow, and articulating those standards so as to make them capable of being followed by those they are intended to govern. ${ }^{141}$ In institutional theory, the hortatory function is an instance of what is termed 'isomorphism': a constraining process which induces one unit in a population to evolve so it resembles other units. ${ }^{142}$ Isomorphism can take a number of forms: 'mimetic' where the structures or norms are imitated because they are seen as being superior or more beneficial, 'normative' where they spread through professional norms, and 'coercive' where they spread through the power of one organisation over another.

The empirical work on judicial review and the administration strongly suggests that the judiciary exerts an isomorphic effect on the administration, but that it is typically coercive rather than mimetic or normative. Much of this is down to the institutional insulation which the history of Crown privilege illustrates. Institutional insulation is, in essence, the inability of one institution to see things from another institution's perspective. The failure of the judiciary to engage with administrative constitutionalism, or even recognise its existence, highlights the extent of institutional insulation between the civil service and the judiciary. Its effects are illustrated by issue of candour. As we have seen, the potential impact of disclosure on candour and completeness was a constant source of concern to departments, and it represented a real issue as those who engaged closely with the administration eventually recognised. Yet, at the same time, the history of Crown privilege also shows that this concern was almost never taken seriously by the judiciary at any time after Duncan $v$ Cammell Laird. A constant theme in legal and judicial responses from Conway v Rimmer to Ex parte Wiley is the view that the issue of candour is at best minor. The assumption that candour does not matter is, however, precisely that: an assumption which has never been tested or verified. Its validity is called into question by the literature on public interest bargains, and reinforced by the fact that candour has been constantly cited not just by administrators in Whitehall, but also by local authorities claiming public interest immunity.

139 See eg L Platt, M Sunkin, and K Calvo, 'The influence of judicial review on bureaucratic decision-making' (2010) 20 Journal of Public Administration Research and Theory 243.

140 See eg S Halliday, 'The influence of judicial review on bureaucratic decision-making' [2000] PL 110.

141 Atiyah (n 8).

142 P DiMaggio and W Powell, 'The Iron Cage Revisited: Institutional Isomorphism and Collective Rationality in Organizational Fields’ (1983) 48 American Sociological Review 147. 
Consider, for example, the 2013 divisional court decision in Worcestershire Safeguarding Children Board v HM Coroner for the County of Worcestershire. ${ }^{143}$ This case arose out of an inquest into a teen in foster care, who killed herself after being temporarily removed from her foster carers. The coroner requested disclosure of the Serious Case Review and Individual Management Review reports. The Board sought, unsuccessfully, to invoke public interest immunity. In evidence submitted on behalf of the Board, its former independent chair used language that closely parallels the points made in the Kent Committee report in defence of class immunity:

My concern over disclosure of the SCR overview report and the IMRs, which is a very substantial concern, related to the principle that this is intended to be a confidential process, culminating in a publicly published report. It is intended to allow all those involved to speak candidly about what happened so that lessons can be learned. That is, and has always been, a crucial aspect to the process as a whole. If that principle is not maintained the practical value of the process will be greatly reduced, if indeed any remains. ${ }^{144}$

The fact that candour continues to be invoked in the same language and for the same reasons by such different authorities should give some pause for thought in relation to whether it is really as irrelevant as the legal responses have assumed. The issue is not, however, merely one of candour, which is simply an illustration of a deeper issue with modern administrative law. It is an article of faith that the task of administrative law is to give effect to principles of good administration. Yet it is a peculiarity of our modern law of good administration that it has been formulated with no reference at all to the administration's own views as to what constitutes good administration, or what administrative bodies need to administer well. In this, it stands in sharp contrast with virtually every other body of law that discharges a hortatory function in relation to professional bodies. The law of professional negligence, which remains dominated by the profession-focused Bolam test, is a clear case in point. ${ }^{145}$

This leads us to the second broader point that emerges from the history discussed in this paper, namely, the issue of legitimacy. In contemporary debates around legitimacy in public law, legitimacy is typically treated as being a feature that flows from the structure of institutions. The history of Crown privilege, and the mutual distrust between the administration and the judiciary that underlay it, in contrast points to a very different dimension of legitimacy - not as an objective fact but as a subjective perception, tied to the way in which a particular institution is perceived as functioning and the types of interests it is perceived as having a predilection to prioritise. To administrators, the judiciary lacked legitimacy when it came to balancing the public interest in good administration against litigants' interest in the administration of justice. Ministers necessarily had a broader horizon in view than the courts, and were in a better position to take all relevant considerations into account than courts were:

the public interest represented by the administration of justice is usually uncomplicated and is one upon which the Minister can obtain advice from his legal

143 Worcestershire Safeguarding Children Board v HM Coroner for the County of Worcestershire [2013] EWHC 1711 (QB).

144 Ibid [76].

145 Bolam v Friern Hospital Management Committee [1957] 1 WLR 582 
advisers whereas the Court is not in a position to take into account the consideration which the Minister must take account of when determining how the possibility of the disclosure of any particular documents in civil proceedings might operate to affect or to have affected the candour and completeness which are required in connection with such documents to the prejudice of the public interest. ${ }^{146}$

At the same time and coming from the opposite position, the judiciary and the legal community challenged the legitimacy of the executive when it came to balancing the public interest in good administration against the public interest in the administration of justice. Critically, the legitimacy that was challenged was not only that of civil servants, but also that of ministers. In Conway, as we have seen above, Lord Reid dismissed the suggestion that a minister could be trusted to balance the competing interests at stake. A minister, he held, had no duty to balance the two interests, and the minister's view on whether a document should be disclosed could not therefore be taken to be final. ${ }^{147}$ Nor was this confined to Conway. In Padfield, ${ }^{148}$ the House of Lords similarly held that courts were free to disregard a minister's view as to the policy of an Act: construction of an Act's policy or purpose was always a matter for the Court. Building on this, a central feature of the development of public interest immunity in judicial review since the Quartet has been the slow loss of ministerial legitimacy in the eyes of the law. In sharp contrast with departmental discussions from Attlee's 1947 memorandum to the Law Reform Committee's review just before Conway, the modern approach to public interest immunity assumes that ministers have no role to play in balancing the interests of good administration against the interest in the administration of justice. In Rogers ${ }^{149}$ and Ex parte Wiley ${ }^{150}$ this is expressly so. The speech in Rogers of Lord Pearson, who as we have seen chaired the Law Reform Committee, is striking in the narrowness of the role it assigns to the minister:

The appropriate Minister has the function of deciding, with the assistance of the Attorney-General, whether or not the public interest on the administrative or executive side requires that he should object to the disclosure of the document or information. ${ }^{151}$

A more recent, and even clearer, sign of this loss of ministerial legitimacy in the eyes of the judiciary is the decision of Ousley $\mathrm{J}$ in $A H K v$ Secretary of State for the Home Department. ${ }^{152}$ In considering the role of the Secretary of State in making public interest immunity claims in proceedings under the British Nationality Act 1981, Ousley J said:

This means that Parliament is taken, perhaps surprisingly, to have imposed a duty on the SSHD herself to strike a balance which could mean that her statutory duty on occasions was to risk national security in the interests of justice for the applicant. If Parliament did so intend, it would also have intended the duty to operate in that

146 TS 58/741, Draft Memorandum from the Treasury Solicitor, July 1965.

147 Conway (n 2) 950.

148 Padfield v Minister of Agriculture, Fisheries and Food [1968] AC 997 (HL).

149 Rogers (n 54).

150 Wiley (n 4).

151 Rogers (n 54) 406.

152 AHK v Secretary of State for the Home Department [2012] EWHC 1117 (Admin). 
way only in the most compelling circumstances. ${ }^{153}$

The import of this is clear. The minister's job is to protect national security. It is the court's job to protect the interests of justice for the applicant. The two are distinct and should not be merged, and to the extent a statute seems to give the minister a role in the latter, that is a surprising exception which should be read narrowly.

It is, at one level, tempting to attribute this loss of legitimacy to the succession of ministerial scandals and misdeeds in the 1960s and thereafter, but the trend would be troubling even if that were true. If the civil service continued to believe that ministers played an important role in balancing public and private interests, then that perception forms part of the administration's understanding of the constitution and, by necessary implication, of their administrative constitutionalism. Seen in this light, the pessimism that underlies the judiciary's position reflects not just a failure to engage with administrative constitutionalism, but a deeper rejection of the need to engage with it, and even of the idea that it could have a productive role to play in identifying how the institutions of the state as a whole might approach the task of balancing the different interests at stake. Nor, in the light of the history discussed here, can this rejection be attributed simply to the way in which the UK's structures relations between civil servants and ministers. Although civil servants have little scope to publicly set out positions of their own, as the history of crown privilege shows they do have a range of other avenues to engage with actors in other branches of the state, including the legal and judicial branch. The insulation that characterises the modern position is very far removed from the many attempts to create an environment for constructive engagement between the judiciary and the administrative services in the years leading to Conway and even in the years after. However, it is a natural consequence of the approach that was set in motion in Conway.

\section{CONCLUSION}

This chapter has sought to argue that Conway $v$ Rimmer remains an important case. Even if the doctrinal points to which it spoke have faded into relative obscurity, it is perhaps the most relevant case in the Quartet in terms of the light it sheds, when seen in historical perspective, on why judicial review remains so controversial in some quarters and why the judicial role in policing the conduct of administration remains so unpopular with the administration and with the executive. Isomorphism is most effective when it is mimetic or normative. Coercive isomorphism of the type that was at play in Conway is likely to be at worst resisted, and at best sullenly accepted, particularly when the institution producing the coercive effect lacks legitimacy in the perceptual sense we have discussed - that is to say, where it is seen as having a propensity to produce outcomes at variance with what the institution subject to the coercive power sees as being its needs - and when it is institutionally insulated from those it governs. This is seen from the history of public interest immunity itself which, until the politically driven changes following the Scott report, was unable to put a final end to the class doctrine.

The issues we have discussed in this chapter also go some way towards pointing to how these issues with judicial review might be resolved, and the law moved closer towards

153 Ibid [27]. 
embodying mimetic and normative isomorphism, if greater account is taken by judges and jurists of two dimensions that are currently for the most part ignored. The first is the existence of what we might call administrative constitutionalism - a public law counterpart to the phenomenon that is called 'rights consciousness' or 'claim consciousness' in private law. The history of Crown privilege shows that the administrative branch did, in fact, have a strong administration-internal constitutionalism. It also shows that there was little, if any, engagement with this administrative constitutionalism. It is this lack of engagement that lies at the heart of the problems we have discussed-both the institutional failure discussed in Section 4, and the administration's own inability to formulate alternative ways of protecting candour that avoided the issues with class privilege, whilst also ensuring that the matters they sought to prioritise would receive adequate legal protection.

Yet there is nothing inevitable about this lack of engagement. Conway itself, for example, would have been less coercive and more normative if it had taken administrative constitutionalism seriously, and worked to guide and refine the manner in which ministers engaged in balancing conflicting interests to ensure that they had greater regard for the interests of justice, without banishing them wholly from the field as Conway did. Private law provides plenty of examples of how this may be achieved, ranging from the Bolitho ${ }^{154}$ exception to Bolam, to the guidance provided to banks in dealing with potential cases of undue influence. ${ }^{155}$ The failure of the courts to so engage with ministers, therefore, highlights the second dimension of which inadequate account is currently taken. Legitimacy, if seen as a perception rather than as an objective feature of an institution, fundamentally implicates institutional efficacy - the extent to which an institution is perceived as having the ability to do something - and is therefore relative rather than absolute. In administrative law scholarship, it is all too frequently assumed that if one institution is not discharging a particular task to a high degree of perfection, then the appropriate response is to assign the task to another institution. It is this that underpins the increasingly strident debates about the excessive 'power' of the judiciary, or about the need to subject the executive to 'legal control'. The history of public immunity suggests that this way of framing the problem is too simplistic. The need, rather, is to think institutionally, and investigate from first principles what the strengths and limitations of all institutions are when taken together, where the relative balance of abilities lies, and, ultimately, what sort of institutional configuration could deal more effectively with the problem in a manner that recognises and seeks to address the full range of legal needs and legal interests implicated in the matter. Recognising the need to so broaden our scholarship is a fitting lesson to draw from the history of Crown privilege fifty years after Conway. 